\title{
Effect of Natural Disasters and Their Coping Strategies in the Kuakata Coastal Belt of Patuakhali Bangladesh
}

\author{
Mohammad Zahangeer Alam ${ }^{*}$, Joan Halsey², Md. Manjurul Haque ${ }^{1}$, Mimi Talukdar'1, \\ Md. Moniruzzaman', Alex R. Crump ${ }^{3}$ \\ ${ }^{1}$ Department of Environmental Science, Bangabandhu Sheikh Mujibur Rahman Agricultural University, Gazipur, \\ Bangladesh \\ ${ }^{2}$ Washington State University, Pullman, WA, USA \\ ${ }^{3}$ Department of Soil and Water Systems, University of Idaho, Moscow, ID, USA \\ Email: *mohammad.alam@wsu.edu
}

How to cite this paper: Alam, M.Z., Halsey, J., Haque, Md.M., Talukdar, M., Moniruzzaman, Md. and Crump, A.R. (2018) Effect of Natural Disasters and Their Coping Strategies in the Kuakata Coastal Belt of Patuakhali Bangladesh. Computational Water, Energy, and Environmental Engineering, 7, 161-182.

https://doi.org/10.4236/cweee.2018.74011

Received: July 4, 2018

Accepted: October 21, 2018

Published: October 24, 2018

Copyright (c) 2018 by authors and Scientific Research Publishing Inc. This work is licensed under the Creative Commons Attribution International License (CC BY 4.0).

http://creativecommons.org/licenses/by/4.0/

(c) (i) Open Access

\begin{abstract}
Bangladesh has experienced a number of severe natural disasters. Most recently, tropical storms Aila, Sidr and Mohaseen have affected the Kuakata coastal belt. These natural disasters have had substantial negative impacts on natural resources. Development of coping strategies for the protection of natural resources across this belt is significantly important. The present research is focused on the effects of tropical storms on crops, humans, fish, livestock and infrastructure. There were 99 fatalities recorded during the Sidr and Aila natural disasters. These disasters impacted 910.94 ha (Sidr) and 973.69 ha (Aila) of cropland. The total number of affected livestock and fishes such as, 18,200 fish ponds, 1209 cattle, 3324 goats, 6888 chickens, 1716 ducks, 103 buffalo and 144 sheep. After tropical cyclones of Sidr, Aila, Heavy rainstorms and Mohaseen 12,970, 17,703, 10,050 and 2500 households respectively reported some form of damage. Cattle, goat, chicken and buffalo were found more injured than other livestock due to the natural disasters of Sidr. Temperature and wind speed were both found to be statistically significant ( $\mathrm{p} \leq$ $0.05)$ with humidity. Climatic parameters trend has been increased significantly since 1979. Regular monitoring of climatic variables, preparedness activities, and coping strategies would be significantly important for this coastal communities.
\end{abstract}

\section{Keywords}

Tropical Storm, Natural Disaster, Coping Strategies, Coastal Belt, 
Preparedness

\section{Introduction}

Bangladesh is located in a region prone to natural disasters [1]. On average, Bangladesh experiences a natural disaster yearly [2]. Natural disasters frequently occur across the coastal belt [3]. Communities in the coastal belt are particularly at risk [4]. This region covers approximately 47,201 square $\mathrm{km}$, encompassing 19 districts [5]. In the coastal region, cyclones, storm surges, riverbank erosion and landslides are recurrent natural disasters [6]. Among these, high intensity cyclones occur either in early summer (March-April) or late in the rainy season (October-November) [7]. For many decades, about 508 recorded cyclones originated in the Bay of Bengal; 17 of these made landfall in Bangladesh [7]. One notable cyclone occurred on April $29^{\text {th }} 1991$, and killed approximately 140,000 people [6] [8] [9]. Another such storm occurred in 1970, killed approximately 300,000 people, 280,000 cattle, and destroyed or severely damaged 100,000 fishing boats and 400,000 homes [2]. Over the last two centuries Bangladesh has been struck by at least 70 storms that resulted in severe damage. The impact of these historic storms was significant, and thus made international headlines [10]. The most recent of these storms was Sidr in 2007 and Aila in 2009. Sidr and Aila had the greatest impact on the coastal region of Bangladesh [10].

It has been estimated that over the last 10 years Bangladesh has lost approximately $3.02 \%$ of GDP due to natural disasters [11]. Additionally, Bangladesh has the highest natural disaster associated mortality rate in the world [12]. Annually $4 \%$ of rice production and $90 \%$ of households are affected by the pre-monsoon and post monsoon season [6]. There are many countries across the world where natural disasters impact crop production. For instance, [13] report battening down the effects of hurricanes on crop production throughout the world. Similarly, a hurricane wind risk and loss assessment of Caribbean agriculture was conducted by [14]. In developing countries crop production is a vital indicator of national income and food security [15]. In Bangladesh food crop production is being severely impacted by various natural disasters [16]. As a result, national economic growth has been declined sharply [6]. In Bangladesh starvation, crop damage, livestock mortality and damage to fisheries are common during storm season [12]. These storms also contribute to skin and several water-borne diseases, including cholera and diarrhea [17]. These diseases are often fatal due to a lack of medical care, shelter, safe food, and potable water [12].

Many factors of climate change seem to be the principle drivers for the increase in extreme natural events [18]. As a result, international attention is focusing on the relationship between extreme weather events and changing climate 
conditions [9] [12]. Coincident with the increase of natural disasters, emergency preparedness has decreased in developing countries [19]. This is paradoxical as studies indicate the increased impact natural disasters have had on natural resources [20]. Tropical cyclones accompanied by heavy rainfall are primarily governed by sea surface temperature [21]. Cyclones induce heavy precipitation and high winds, resulting in flooding and storm surges [22] [23] [24].

The government of Bangladesh has been conducting research on the impacts of natural disasters in collaboration with develop countries. This research primarily focuses on the effectiveness of disaster preparedness plans, the use of cyclone shelters, and early warning systems [10]. Research is also being carried out to determine how the effects of global warming can be mitigated through the implementation of various coping strategies [25]. Cyclone coping strategies are dependent upon the demographics and socio-economic conditions in cyclone-prone coastal villages in Bangladesh [26]. In these areas people are accustomed to adjusting their lifestyle and developing their own coping strategies [10]. Local impact prevention and mitigation strategies have been shown to significantly minimize the vulnerability of people in coastal communities [26]. Early warning systems and government/non-government partnerships for disaster relief and rebuilding efforts have been shown to be effective disaster management strategies for lessening the long-term impacts experienced by poor communities in disaster prone areas [26].

Tropical storms cannot be prevented, but damage may be mitigated through effective management strategies [12]. The impact cyclones have on local populations can be lessened through the implementation of effective warning systems, the construction of cyclone shelters, and formulation of emergency evacuation and preparedness plans [8]. Integrated disaster risk management programs incorporate these strategies in a manner that includes; building awareness at school and community levels, facilitating the development of local disaster management and rescue plans, aiding in the formation of disaster risk reduction (DRR) groups, improving training to adequately asses' vulnerabilities to natural resources, and increasing search and rescue capacities in a variety of disaster prone areas [12]. Many studies have projected the remarkable impact of tropical cyclones on agriculture throughout the world [13]. The Coastal belt is significantly important for agriculture production due to its fertility and productivity, so this research provides a quantitative risk and loss assessment of agriculture, livestock, humans and other infrastructure across the Kuakata coastal belt in Bangladesh. For this reason, this research is significantly important for the protection of natural resources from the hit of natural disasters across the coastal belt in Bangladesh. Combining advanced management strategies for natural disaster mitigation is a more pragmatic approach than current relief efforts [27]. We studied the impacts of natural disasters on crops, livestock, fisheries and humans. We also examined the correlation between climatic variables and preparedness with coping strategies for the reduction of natural disasters at Kuakata 
coastal region of Bangladesh. We found natural disasters negatively affected crops, households, fisheries and livestock due to the variation of climatic parameters in Bangladesh as well as throughout the world [13]. It hypothesizes continuous monitoring of climatic parameters, and natural disaster frequency on the coastal belt in Bangladesh will be useful for the protection of natural resources.

\section{Materials and Methods}

\subsection{Description of Study Areas}

The Kuakata coastal belt of Kalapara Upazila is in the south-western part of Bangladesh, and is susceptible to periodic cyclonic storms. It is located between $21^{\circ} 48^{\prime}$ and $22^{\circ} 05^{\prime}$ north latitude and between $90^{\circ} 05^{\prime}$ and $90^{\circ} 20^{\prime}$ east longitude [28]. Kalapara Upazila is bounded by Amtali Upazila of the Barguna district to the north and west, the Bay of Bengal on the south, Rabnabad channel and Galachipa Upazila on the east [29]. The total area of Kalapara Upazila is 491 square kilometers and the population is 238,000 [30]. The study area is highlighted in Figure 1 and Table 1.

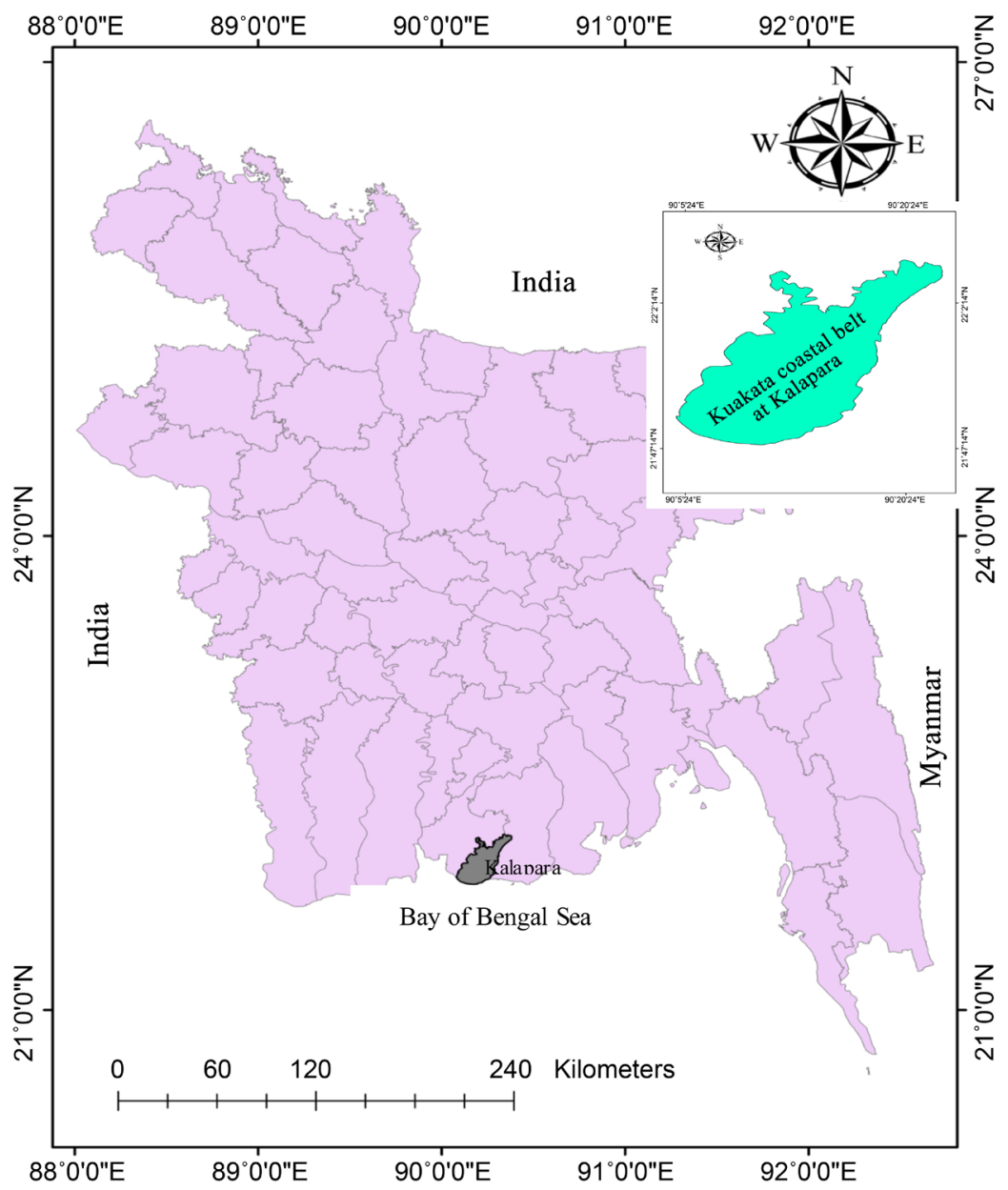

Figure 1. Study area on a Bangladesh map. 
Table 1. Description of study areas in the Kuakata coastal belt of Kalapara Upazila.

\begin{tabular}{|c|c|c|c|c|c|c|c|c|}
\hline $\begin{array}{c}\text { Total area } \\
\left(\mathrm{km}^{2}\right)\end{array}$ & $\begin{array}{l}\text { Total population } \\
\qquad(000)\end{array}$ & $\begin{array}{c}\text { Number of } \\
\text { Union }\end{array}$ & Agricultural resources & $\begin{array}{l}\text { Cropping } \\
\text { pattern }\end{array}$ & Topography & $\begin{array}{c}\text { Source of } \\
\text { irrigated water }\end{array}$ & $\begin{array}{c}\text { Major } \\
\text { problems }\end{array}$ & $\begin{array}{c}\text { Total } \\
\text { cyclone center }\end{array}$ \\
\hline 491 & 238 & 12 & $\begin{array}{l}\text { Rice, pulse crops, sesame, } \\
\text { spices crops, potato's, } \\
\text { melon, sunflower, maize, } \\
\text { wheat, betel leaves, } \\
\text { livestock and fisheries }\end{array}$ & 25 & Flat & $\begin{array}{l}\text { Rivers, Bay of } \\
\text { Bengal and } \\
\text { rainfall }\end{array}$ & $\begin{array}{l}\text { Natural disaster and } \\
\text { Hazards-Cyclones } \\
\text { and Salinity }\end{array}$ & 25 \\
\hline
\end{tabular}

\subsection{Inception Meeting}

A 5-day inception meeting was held in Kalapara Upazila between the Department of Agricultural Extension (DAE), Bangladesh Water Development Board (BWDB), Bangladesh Jute Research Institute (BJRI), Local Government Engineering Development (LGED), and Natural Disasters Management office on $20^{\text {th }}$ March, 2016. Attendees included volunteers from the Cyclone Preparedness Program (CPP), and government officials from Kalapara Upazila. Discussion topics included; type and severity of natural disasters and the effect on crops, livestock, fisheries, schools, and religious institutions. During this meeting we collected data on the impacts of tropical cyclones to crops, fisheries, livestock, roads, households, and humans.

\subsection{Collection of Data Regarding Impacts of Natural Disasters on Environment}

Based upon discussions held at the inception meeting, we elected to examine the impacts of several historic natural disasters. These include Aila, Sidr and Mohaseen, all of which struck the Kuakata Coastal belt. We noted the impacts of these natural disasters on humans, crops, fisheries, and livestock. These data were gathered from the Upazila Disaster Management Bureau office, Department of Agricultural Extension, Department of Fisheries, and the Department of Livestock. Information regarding the impacts of cyclonic natural disasters on households, roads, educational, and religious institutions was gathered from the Upazila Disaster Management Bureau office.

\subsection{Information Regarding Existing Coping Strategies and Preparedness Program}

Information pertaining to existing coping strategies employed by the Bangladeshi government, individuals, non-governmental organization (NGO), and educational institutions was acquired from the Upazila Disaster Management $\mathrm{Bu}$ reau office of Kalapara. We also collected information related to current preparedness levels including, signaling, evacuation and relocation plans, search and rescue, first aid, and systems which are in place for providing relief to local communities during natural disasters (Figure 2 and Table 6).

\subsection{Data about Climatic Parameters}

We examined climate data for the last 36 years including; temperature, rainfall, 
humidity, and wind speed. Data were collected from the Bangladesh Meteorological Department, Climate Division, Agargaon, Dhaka-1207. We noted average yearly status of rainfall, temperature, humidity and wind speed for Kuakata coastal regions (Figure 3).

\subsection{Statistical Analysis}

Pearson correlation coefficients were determined for relevant climate parameters using Statistical Package for the Social Sciences (SPSS). Significance levels for correlation between temperature, rainfall, humidity and wind speed were analyzed using R (3.2.2 version). Trend of climatic parameters changes since 1979 to 2015 were analyses using $R$ also. Effect of natural disasters on human and livestock was analyzed using "Z" score.

\section{Results}

\subsection{Effect of Natural Disasters}

The natural disasters, which struck the Kuakata coastal belt impacted human populations, crops, fisheries, livestock, households, roads, and educational and religious institutions.

\subsubsection{Human}

The Kuakata coastal belt of Patuakhali was struck by tropical storms Sidr, Aila, and Mohaseen, which originated in the Bay of Bengal in 2007, 2009, and 2013. In 2010 the region was affected by numerous storms and heavy rainfall. Sidr reportedly killed 94 people, disabled 96, wounded 1678 and affected 3247 families. Tropical storm Aila killed 5 people, disabled 6, wounded 145 and affected 5750 families. In 2010 storms and heavy rainfall affected 5907 families. About 500 families were affected by tropical storm Mohaseen in 2013. Minimum number of people was death, wounded and paralyzed due to heavy rain and Mohaseen cyclones. According to the analysis of " $\mathrm{Z}$ score" number of affected families was positively increased due to the tropical storms of Sidr, Aila, and Mohaseen rather than other impacts such as, death, handicapped and wounded (Table 2).

\subsubsection{Crops}

About 910.94, 973.69, 20 and 15 ha cropping areas were fully (100\%) affected by the natural disasters of Sidr, Aila, heavy storms and Mohaseen cyclones. Similarly, 161.94, 243.32, 1344.13 and 5674.09 ha area were partially (50\%) affected by tropical storms Sidr, Aila, Mohaseen and heavy storms. In addition, 189.88, 202.43, 2 and 5 ha of arable land was damaged to the salinization as a result of Sidr, Aila, heavy storms and Mohaseen (Table 3).

\subsubsection{Fisheries}

In the Kuakata Coastal Belt 18200 fish ponds were affected (100\%) by each natural disaster of Sidr, Aila, and Mohaseen due to the intrusion of saline water. As a result of this, 1500 metric tons of fish were lost by these natural storms (Table 3). 
Table 2. Effect of natural disasters on human across the Kuakata coastal belt.

\begin{tabular}{|c|c|c|c|c|c|c|c|c|}
\hline \multirow[b]{2}{*}{ Types of impacts } & \multicolumn{8}{|c|}{ Natural disasters } \\
\hline & Sidr, 2007 & $\begin{array}{l}\text { “Z” score } \\
\text { values }\end{array}$ & $\begin{array}{l}\text { Aila, } \\
2009\end{array}$ & $\begin{array}{l}\text { “Z” score } \\
\text { values }\end{array}$ & $\begin{array}{c}\text { Mohaseen, } \\
2013\end{array}$ & $\begin{array}{l}\text { “Z” score } \\
\text { values }\end{array}$ & $\begin{array}{l}\text { Heavy storm and } \\
\text { rain fall, } 2010\end{array}$ & $\begin{array}{c}\text { “Z” score } \\
\text { values }\end{array}$ \\
\hline Death toll & 94 & -0.78 & 5 & -0.52 & 1 & -0.50 & 1 & -0.50 \\
\hline Paralyzed/handicapped people & 96 & -0.78 & 6 & -0.52 & 3 & -0.50 & 2 & -0.50 \\
\hline Wounded & 1678 & 0.26 & 145 & -0.47 & 2 & -0.50 & 3 & -0.50 \\
\hline Affected families & 3247 & 1.30 & 5750 & 1.50 & 500 & 1.50 & 5907 & 1.50 \\
\hline
\end{tabular}

Table 3. Impacts of tropical storms on crops and fisheries in the Kuakata coastal region of Kalapara Upazila.

\begin{tabular}{|c|c|c|c|c|c|c|}
\hline \multirow[b]{2}{*}{$\begin{array}{l}\text { Natural } \\
\text { Disaster }\end{array}$} & \multirow[b]{2}{*}{ Date } & \multicolumn{3}{|c|}{ Crops } & \multicolumn{2}{|c|}{ Fisheries } \\
\hline & & $\begin{array}{l}\text { Fully affected } \\
\text { cropping } \\
\text { areas (ha) }\end{array}$ & $\begin{array}{l}\text { Partially affected } \\
\text { cropping areas } \\
\text { (ha) }\end{array}$ & $\begin{array}{c}\text { Salinity } \\
\text { affected } \\
\text { areas (ha) }\end{array}$ & $\begin{array}{c}\text { Total fish } \\
\text { pond }\end{array}$ & $\begin{array}{l}\text { Affected fish } \\
(\mathrm{Mt}) / \text { water } \\
\text { bodies (ha) }\end{array}$ \\
\hline Sidr & $\begin{array}{c}2007 \text {, } \\
\text { November }\end{array}$ & 910.94 & 161.94 & 189.88 & $\begin{array}{c}18,200 \\
(450 \mathrm{ha})\end{array}$ & $1500 / 450$ \\
\hline Aila & 2009, May & 973.69 & 243.32 & 202.43 & $\begin{array}{c}18,200 \\
(450 \mathrm{ha})\end{array}$ & $1500 / 450$ \\
\hline $\begin{array}{l}\text { Heavy storm } \\
\text { and rainfall }\end{array}$ & 2010, October & 20 & 5674.09 & 2 & 20 ha & 15 ha \\
\hline Mohaseen & 2013, May & 15 & 1344.13 & 5 & $\begin{array}{c}18,200 \\
(450 \mathrm{ha})\end{array}$ & $1500 / 450$ \\
\hline
\end{tabular}

\subsubsection{Livestock}

Total number of recorded livestock fatalities during Sidr, Aila and Mohaseen were; 1209 cattles, 3324 goats, 6888 chickens, 1716 ducks, 103 buffalo, and 144 sheep. These storms further affected (injured) 52,205 cattle, 18,801 goats, 409,002 chickens, 25,505 ducks, 20,607 buffalo and 3503 sheep. These storms destroyed approximately 321 tons of livestock feed. Records indicate that 12 dairy farms and 62 poultry farms were severely damaged. According to the $\mathrm{Z}$ score, cattle, goat, chicken and buffalo were found more injured than other livestock due to the tropical disasters of Sidr. The number of chicken was found positively injured due to the natural disasters of Aila also. On the other hand, Maximum number of goats, chicken and ducks were death rather than other livestock during the natural disaster of Mohseen. Poultry farm were found damaged because of the tropical disasters frequency (Table 4).

\subsubsection{Households, Roads, Educational and Religious Institutes}

The recorded number of households damaged by Sidr and Aila were 12,970 and 17,703. An additional 10,050 and 2500 household were found damaged by storms with heavy rainfall and Mohaseen cyclones, respectively. During Sidr and Aila a number of educational institutions were also heavily damaged (195 and 68). The number of affected religious institutions recorded during these storm 
Table 4. Effect of natural disasters on livestock across the Kuakata coastal belt.

\begin{tabular}{|c|c|c|c|c|c|c|c|}
\hline \multirow{2}{*}{$\begin{array}{l}\text { Types of } \\
\text { impacts }\end{array}$} & \multirow{2}{*}{$\begin{array}{l}\text { Livestock's } \\
\text { (No.) }\end{array}$} & \multicolumn{6}{|c|}{ Natural disasters } \\
\hline & & Sidr, 2007 & $\begin{array}{l}\text { “Z” score } \\
\text { values }\end{array}$ & Aila, 2009 & $\begin{array}{l}\text { “Z” score } \\
\text { values }\end{array}$ & $\begin{array}{c}\text { Mohaseen, } \\
2013\end{array}$ & $\begin{array}{c}\text { “Z” score } \\
\text { values }\end{array}$ \\
\hline \multirow{6}{*}{ Death Toll } & Cattle & 1185 & -0.55 & 22 & -0.28 & 2 & -0.49 \\
\hline & Goat & 3285 & -0.35 & 27 & -0.28 & 12 & 0.17 \\
\hline & Chicken & 5821 & -0.12 & 1032 & -0.27 & 35 & 1.67 \\
\hline & Ducks & 1659 & -0.50 & 2 & -0.28 & 55 & 2.98 \\
\hline & Buffalo & 101 & -0.65 & 1 & -0.28 & 1 & -0.55 \\
\hline & Sheep & 134 & -0.65 & 8 & -0.28 & 2 & -0.49 \\
\hline \multirow{6}{*}{$\begin{array}{c}\text { Injured } \\
\text { livestock }\end{array}$} & Cattle & 40,000 & 3.06 & 12,200 & -0.16 & 5 & -0.29 \\
\hline & Goat & 16,000 & 0.83 & 2800 & -0.26 & 1 & -0.55 \\
\hline & Chicken & 9000 & 0.18 & 400,000 & 3.61 & 2 & -0.49 \\
\hline & Sheep & 3200 & -0.36 & 300 & -0.28 & 3 & -0.42 \\
\hline & Duck & 7500 & 0.04 & 18,000 & -0.11 & 5 & -0.29 \\
\hline & Buffalo & 18,000 & 1.01 & 2600 & -0.26 & 7 & -0.16 \\
\hline \multicolumn{2}{|c|}{ Livestock feed (ton) } & 300 & -0.63 & 20 & -0.28 & 1 & -0.55 \\
\hline \multicolumn{2}{|c|}{ Dairy farm (No.) } & 10 & -0.66 & 1 & -0.28 & 1 & -0.55 \\
\hline \multicolumn{2}{|c|}{ Poultry farm (No.) } & 37 & -0.65 & 15 & -0.28 & 10 & 0.03 \\
\hline
\end{tabular}

events was 886,285 and 106. During this period $166 \mathrm{~km}$ of roadway were heavily damaged (Table 5).

\subsection{Existing Natural Disaster Preparedness Plans}

Existing preparedness plans include signaling, evacuation, search and rescue, emergency medical aid, and post-disaster activities. For signaling, signal numbers 1 - 3 indicate oral forecasting from person to person and raising signal flag one. Signal No. 4 - 7 indicates that the storm warning is announced with a megaphone and signal flag two is raised. Signal No. 7 - 8 indicates warning announcements are made by Loud Speaker, Megaphone, and Siren, and signal flag 3 is raised. The second criterion, evacuation, includes the transfer of women, children, the elderly and disabled into the cyclone shelters. Search and rescue groups were responsible for damage surveys, stretching, laddering, raft making, and ensuring safe waterways after a cyclone. Emergency medical aid is necessary to ensure that affected people receive adequate medical attention. Post disaster activities include disaster relief and aid distribution (Figure 2).

\subsection{Existing Coping Strategies for Natural Disasters}

In disaster prone areas current coping strategies are implemented by government, educational institutions and NGO's. These strategies include afforestation incentives and programs, construction of dams and sluice gates, and the 


\begin{tabular}{|c|c|c|c|c|}
\hline & \multicolumn{2}{|c|}{$\begin{array}{l}\text { Existing preparedness } \\
\text { (5 group) }\end{array}$} & & \\
\hline $\begin{array}{ll}\text { Signaling: } \\
\quad \text { Signal No. 1-3: } \\
\text { Person to person oral } \\
\text { communication } \\
\text { Signal flag } 1 \text { is } \\
\text { raised. } \\
\text { Signal No. 4-7: } \\
\text { Announcement by } \\
\text { megaphone. Signal } \\
\text { flag } 2 \text { is raised. } \\
\text { Signal No. 8-7: } \\
\text { Announcement by } \\
\text { loud speaker, } \\
\text { megaphone, and } \\
\text { siren. Signal flag } 3 \text { is } \\
\text { raised. }\end{array}$ & $\begin{array}{l}\text { Evacuation and } \\
\text { Relocation: } \\
\text { Volunteers and } \\
\text { government } \\
\text { agencies evacuate } \\
\text { and transfer } \\
\text { vulnerable } \\
\text { populations to } \\
\text { cyclone shelters. } \\
\text { This group includes } \\
\text { the physically } \\
\text { disabled, elderly, } \\
\text { women and } \\
\text { children. }\end{array}$ & $\begin{array}{l}\text { Search and Rescue: } \\
\text { Operations are } \\
\text { carried out by a } \\
\text { group of volunteers } \\
\text { who are trained for } \\
\text { search and rescue } \\
\text { operations by the } \\
\text { Cyclone } \\
\text { Preparedness } \\
\text { Program (CPP). } \\
\text { They are responsible } \\
\text { for post catastrophe } \\
\text { surveys, stretching, } \\
\text { laddering, raft } \\
\text { making, and river/sea } \\
\text { safety. }\end{array}$ & $\begin{array}{l}\text { Medical and First } \\
\text { Aid: } \\
\text { Post cyclonic storm } \\
\text { event, volunteers } \\
\text { with first aid and } \\
\text { medical training will } \\
\text { begin searching for } \\
\text { injured people. Their } \\
\text { main function is to } \\
\text { serve the seriously } \\
\text { injured, and address } \\
\text { injuries that include; } \\
\text { lacerations, broken } \\
\text { bones, exhaustion, } \\
\text { and drowning. }\end{array}$ & $\begin{array}{l}\text { Relief: } \\
\text { Generally, post } \\
\text { disaster } \\
\text { activities } \\
\text { include, } \\
\text { distribution of } \\
\text { relief supplies, } \\
\text { rehabilitation of } \\
\text { affected people, } \\
\text { and health \& } \\
\text { sanitation } \\
\text { management. }\end{array}$ \\
\hline
\end{tabular}

Figure 2. Flow chart of existing preparedness activities for natural disasters in the Kuakata coastal belt.

Table 5. Impacts of tropical storms on households, roads, educational, and religious institutions in the Kuakata coastal region of Kalapara Upazila.

\begin{tabular}{cccccc}
\hline Natural Disasters & Year & $\begin{array}{c}\text { Households } \\
(\text { No. })\end{array}$ & $\begin{array}{c}\text { Educational } \\
\text { institute (No.) }\end{array}$ & $\begin{array}{c}\text { Religious } \\
\text { institute (No.) }\end{array}$ & Roads (km) \\
\hline Sidr & 2007, November & 12,970 & 195 & 886 & 80 \\
Aila & 2009, May & 17,703 & 68 & 285 & 25 \\
$\begin{array}{c}\text { Heavy storm and } \\
\text { rainfall }\end{array}$ & 2010, October & 10,050 & 5 & 106 & 21 \\
Mohaseen & 2013, May & 2500 & 3 & 1 & 40 \\
\hline
\end{tabular}

construction of cyclone shelters. In addition, increased public awareness of disaster plans has been achieved through education and outreach which include implementation of first aid training programs, search and rescue training, and cultural demonstrations of natural disasters through drama, folk songs, public rallies, and school feeding (Table 6).

\subsection{Climatic Parameters}

We analyzed local climate data from the Kutakata coastal belt from 1979-2015. This data set included records for temperature, rainfall, humidity and wind speed.

\subsubsection{Temperature}

The highest recorded temperature was $27.1^{\circ} \mathrm{C}$ in 1979 . The lowest temperature was $25.5^{\circ} \mathrm{C}$, and was recorded in 1997 and 2013. Temperature variations were minimal between 1979 and 2015 (Figure 3). Temperature was negatively correlated with rainfall and humidity. A positive correlation was found between temperature and wind speed. Temperature was significantly $(\mathrm{p} \leq 0.05)$ correlated 
Table 6. Existing coping strategies for tropical storms in the Kuakata coastal belt.

\begin{tabular}{|c|c|c|c|}
\hline Government & Social & Educational institute & NGO's \\
\hline $\begin{array}{l}\text { Afforestation activities; } \\
\text { Dam construction; } \\
\text { Building sluice gates; } \\
\text { Create public awareness; } \\
\text { through film, video shows, } \\
\text { and publicity campaign; } \\
\text { Erect and maintain cyclone } \\
\text { shelters. }\end{array}$ & $\begin{array}{l}\text { Motivation to increase } \\
\text { social benefits for creating } \\
\text { forested areas on } \\
\text { homestead; } \\
\text { Increase the awareness } \\
\text { among the community } \\
\text { people regarding tools for } \\
\text { preparation and reducing } \\
\text { impacts of natural disasters. }\end{array}$ & $\begin{array}{l}\text { Educate public children on the } \\
\text { effects of natural disasters and } \\
\text { existing coping strategies; } \\
\text { Arrange training sessions and } \\
\text { seminars regarding the effect of } \\
\text { natural disasters and benefits } \\
\text { associated with preparedness } \\
\text { activities. }\end{array}$ & $\begin{array}{l}\text { Provide training for first aid, search and } \\
\text { rescue, and leadership; } \\
>\text { Develop public educational demonstrations } \\
\text { using drama, folk songs and public rallies to } \\
\text { communicate natural disaster } \\
\text { preparedness; } \\
\text { School feeding for awareness build up; } \\
>\text { Implement afforestation programs; } \\
>\text { Design and construction of cyclone shelters. }\end{array}$ \\
\hline
\end{tabular}

with humidity (Table 7). Since 1979, temperature trend has been found significantly increased $(0.01<\mathrm{p} \leq 0.05)$ (Table 8$)$.

\subsubsection{Rainfall}

The recorded rainfall ranged from 156 to $292.5 \mathrm{~mm}$ between 1979 and 2015. The highest recorded rainfall was in 1995 and 2001. Similar rainfall levels were recorded in 2011, 2013 and 2015 (Figure 3). Rainfall was positively correlated with humidity and wind speed. There is no significant relationship between rainfall and other climatic parameter. Since 1979, rainfall trend has been increased significantly $(0.05<\mathrm{p} \leq 0.1)$ (Table 7 and Table 8).

\subsubsection{Humidity}

The average humidity ranged from 74 to $88 \%$ for the 36 -year period covered by our data set. The lowest humidity percentages were found in 1980 and the highest was in 1987 (Figure 3). Wind speed was negatively correlated with humidity. This relationship was statistically significant ( $\mathrm{s}$ 0.05) (Table 7). Since 1979, humidity trend has been increased significantly $(0.05<\mathrm{p} \leq 0.1)$ (Table 8$)$.

\subsubsection{Wind Speed}

The highest wind speed, 7.9 knots, was recorded in 1979. The lowest wind speed, 3 knots, was recorded in 1987 (Figure 3). Wind speed was positively correlated with temperature and rainfall, and was negatively correlated with humidity. This relationship was statistically significant $(\mathrm{p} \leq 0.05)$ (Table 7). Since 1979, wind speed trend has been found statistically insignificant different $(0.05<\mathrm{p} \leq 0.1)$ (Table 8).

\section{Discussion}

\subsection{Natural Disasters in Coastal Belt of Bangladesh}

Over the last 100 years Bangladesh has experienced 53 major cyclones. The intensity and frequency of cyclones is the greatest in the Kuakata coastal belt [7]. In recent years sustained population growth, in conjunction with the aggressive development of vulnerable coastal areas, has led to an increase in natural disaster related injuries and fatalities to humans, crops, livestock, fisheries and other infrastructure in Bangladesh as well as throughout the world [13] [14] [31] [32]. 
450

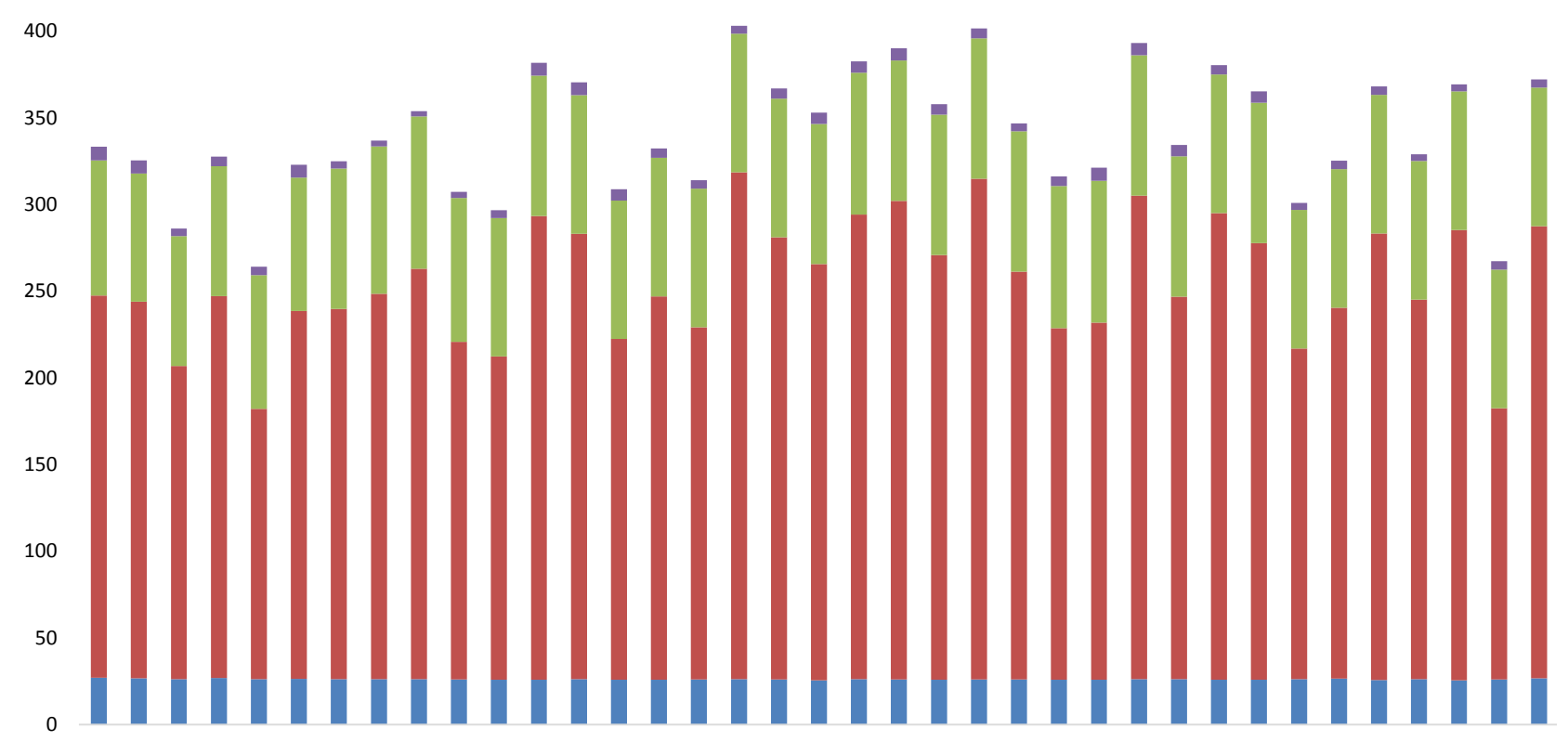

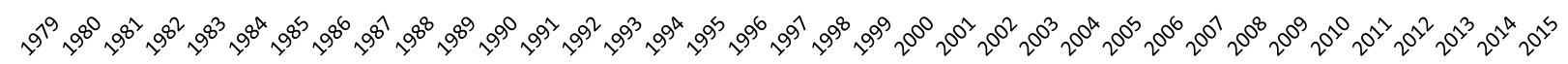

Figure 3. Variation of yearly average temperature, rainfall, humidity and wind speed in the Kuakata coastal region in Bangladesh for last thirty-six years.

Table 7. Correlation between climatic parameters in the coastal belt during the year of 1979 to 2015 .

\begin{tabular}{ccccc}
\hline Climatic parameters & Temperature $\left({ }^{\circ} \mathrm{C}\right)$ & Rainfall $(\mathrm{mm})$ & Humidity $(\%)$ & Wind speed (Knots) \\
\hline Temperature ${ }^{\circ} \mathrm{C}$ & 1 & & & \\
Rainfall $(\mathrm{mm})$ & -0.133058442 & 1 & & \\
Humidity (\%) & $-0.409135861^{* *}$ & 0.244974067 & 1 & 1 \\
Wind speed (Knots) & 0.167155225 & 0.234482349 & $-0.329081057^{* *}$ & 1 \\
\hline
\end{tabular}

${ }^{*}$ Indicate significantly correlated at $5 \%$ level of significance.

Table 8. Coefficient trend of climatic parameters across the Kuakata coastal belt since 1979 to 2015.

\begin{tabular}{cccc}
\hline Climatic Parameter & Estimated trend & Standard Error & R-Square \\
\hline Temperature & $-12.085^{\star *}$ & 5.191 & 0.134 \\
Rainfall & $0.081^{\star}$ & 0.051 & 0.068 \\
Humidity & $1.162^{\star}$ & 0.703 & 0.072 \\
Wind Speed & -1.138 & 1.347 & 0.02 \\
\hline
\end{tabular}

${ }^{* *}$ Indicate significant difference at $5 \%(0.01<\mathrm{p} \leq 0.05)$ level of significance, ${ }^{*}$ indicate significant difference at $10 \%(0.05<\mathrm{p} \leq 0.1)$ level of significance.

The mortality rates have been linked to flash flooding and storm surges triggered by cyclones [33]. Natural disasters continue to have a negative effect on societies 
for many years [34]. Primarily this effect includes persistent injuries, illness, damaged agriculture sector and other infrastructure (Tables 2-5). Natural disasters represent a significant threat to developing countries [35]. Bangladesh's geographical position along with prevailing climatic conditions, frequently result in devastating natural disasters [32].

Like many developing countries Bangladesh is an agrarian society [36]. Crop productivity is higher in the coastal belts than other regions of Bangladesh [37]. The Kuakata coastal belt produces rice, lentils, sesame, spices, potatoes, water melon, sunflower, maize, wheat, and betel leaves. Over the last few decades, crop production has been negatively affected by several cyclonic natural disasters [37]. These disasters might further effect agricultural trading flows and manufacturing subsectors, including the textile and food processing industries [38]. We found that 1884.62 ha in crop production were damaged in the Kalapara coastal belt over this period (Table 3). Similar studies conducted on natural disasters and their effects on agriculture, food security and natural resources in Philippines, concluded that natural disasters had a significant negative effect on food security [13] [39]. Over the last three decades, in developing countries natural disasters have led to an increase in damage to food crops thus putting them at an increased risk for food insecurity [38]. Comparable studies in the coastal belt of Bangladesh, rice, chili, vegetable and fruit yields declined 7.5\%, 11.66\%, $10 \%$ and $9.16 \%$ respectively due to tropical storms [40].

Fish and livestock are important food resources that have a direct benefit to human health [41]. These products can strengthen one's immune system by providing a complete protein [40]. Unfortunately, these food sources are declining due to increased storm intensity in coastal region of Bangladesh. Fish in riverine $(70.83 \%)$ and pond $(33.33 \%)$ ecosystems were affected by the salt-water intrusion events that accompanied Aila and Sidr. These storms also injured cattle $(18 \%)$, goats $(14 \%)$, buffalos $(21 \%)$, chickens $(10.09 \%)$, ducks $(8.82 \%)$ and pigeons (24\%) [40]. The highest incidence of cattle (500) and poultry fatalities $(25,000)$ was recorded in the coastal belt of the Patuakhali district. Dairy farms with several tons of dairy products were also damaged (Table 4). Damage to fishery resources was particularly devastating with 1026 fish rearing ponds and 8218.62 ha in shrimp production destroyed [42]. Similarly, we found that fish, cattle, goats, buffalos, sheep, chicken and ducks were severely affected in the Kuakata coastal belt of Bangladesh.

Usually people in the Kuakata coastal regions live with a great deal of environmental risk [43]. Because of this, these communities tend to adapt to natural disasters. Due to this adaption and the frequency with which storms occur, most people do not want to evacuate their homes when severe storms threaten. The reason most often cited is that they fear loss of property. This inflexible attitude often results in people experiencing the devastating effects of natural disasters [44]. When tropical cyclone Sidr struck the south west coast of Bangladesh with winds up to 240 kilometers per hour, the resulting widespread flooding caused 
damage to homes, roads and bridges, sanitation infrastructure, interrupted electrical service and downed communications. Drinking water was contaminated and many sources were inundated with saline water from tidal surges [45]. Cyclone Sidr impacted $8075 \mathrm{~km}$ of roads in 11 of the 30 affected districts. Of the $8075 \mathrm{~km}, 1714 \mathrm{~km}$ were destroyed, and $6361 \mathrm{~km}$ were partially damaged. Most of the affected roads were on embankments and were destroyed by the high tidal surge [45].

\subsection{Climatic Variability and Natural Disasters}

Recently, climate change has come to the forefront as a leading environmental issue [46]. Climate change includes any significant shift in temperature, rainfall, humidity and wind speed [47]. For decades these climatic parameters have been changing throughout the world. Due to changing climatic parameters, natural disasters are increasing [46]. Developing countries in particular are facing incredible challenges to their social and economic existence. Coastal areas are particularly susceptible to the increased frequency and intensity of extreme weather events [48]. The coastal belt of Bangladesh is at extreme risk due to geographical position [49]. For the last two decades, the earth's temperature has steadily been increasing in the world as well as in the coastal belt of Bangladesh [48]. Natural disasters such as drought, high intensity storms, and tropical cyclones with high wind speeds are extremely visible [50]. Temperature is connected with weather-related natural disasters [51]. The current average global temperature is likely higher than at any point over the last 2000 years [20] [48]. Cyclones are weather events with strong winds that circulate around low-pressure areas. Tropical cyclones typically form above warm seas, with water temperatures around $26.5^{\circ} \mathrm{C}$ [20]. Temperatures and other climate parameters that were recorded at the $\mathrm{Ku}$ akata coastal belt prior to the storm events were similar (Figure 3). In fact, this climatic parameter has been increased across the Kuakata coastal belt since many decades (Table 8).

Climate change is a principle driver of increasing the frequency and intensity of tropical cyclones [52]. The destructiveness of cyclones has increased over the last 30 years [53]. The number of cyclones has nearly doubled since 1970 [54]. The frequency of these natural disasters is influenced by anthropogenic changes [55]. Climate change is impacting environmental conditions due to changes in wind speed and rainfall patterns [55]. The coastal region of Bangladesh has experienced several natural disasters due to changing climate parameters [56]. Some of these climate variables are positively correlated. The correlation between humidity and temperature and wind speed is statistically significant (Table 7). Since many decades, trend of climatic parameters changes has been increased significantly across the Kuakata coastal belt in Bangladesh (Table 8). Climate change is likely to increase the frequency, intensity, duration, and spatial distribution of a range of extreme weather events over the coming decades [20]. Collaborations between climate scientists, health researchers, policy-makers, 
as well as the disaster community, are essential for jointly developing adaptation strategies [57]. Tropical cyclones with 5\% - 10\% increases in peak wind speeds, and $20 \%-30 \%$ increases in precipitation, have been increasing for several decades [20]. Vulnerability of coastal regions to tropical cyclones is a concern, with these storms causing a large amount of damage in coastal regions [58]. Climate change should not be addressed in an isolated manner as it has significant connectivity with natural disasters [59].

Climate change is not only a topic discussed in the physical sciences, but also public policy circles [60]. Increased public attention and research on natural disasters has led to a number of possible relationships being found between climate change and disaster incidents [61]. Natural disasters included both atmospheric and non-atmospheric-related phenomena [62]. Disparities exist between atmospheric and non-atmospheric-related natural disasters. For instance, Hurricanes making landfall in US have resulted in damages totaling 42 billion USD [63]. In October 2005 Hurricane Katrina, which appears to have been the costliest hurricane ever, made landfall and the accompanying damages were estimated in excess of USD 100 billion [64]. Worldwide 2005 witnessed the highest number of severe hurricanes and high intensity storms [63].

Temperature and relative humidity are strongly correlated. The level of cross-correlation between air temperature and relative humidity is similar in different climatic zones throughout the world [65]. Tropical storms are often due to the delayed arrival or early retreat of south-west monsoons associated with low precipitation. In addition, initiation and intensification of storms may also result from heat waves. Seasonal temperature variations, frequent heat waves during summer months, and inconsistent rainfall during the rainy (monsoon) season, often result in recurrent natural disasters. Rainfall and temperature have a direct influence on one another [66].

Tropical cyclones occur frequently along coastal regions, which can result in severe disturbances to tropical rain forests and mangrove forest. These forest areas are negatively affected by extreme temperature variation. Because of this climate variability, fragmented rain forests which are common in the coastal region are particularly vulnerable to cyclone damage [67]. Shifts in local climatic parameters, has negatively affected natural resources, which in turn has resulted large economic losses to coastal belt regions worldwide. In the coastal belt of Bangladesh, tropical storms have been a leading contributor to overall declines in quality of life. It is highly devastating news that due to the changes of climatic parameters since many decades, coastal communities in Bangladesh might be faced severe natural disasters as well as Aila, Sidr and Mohaseen for in future.

\subsection{Mitigation of Natural Disasters}

Mitigating natural disasters includes both pre and post disaster activities.

\subsubsection{Pre Disaster Activities}

1) Early Warning Systems 
Early warning systems (EWS) are a critical life-saving tool for storms, bushfires and cyclones [68]. An effective EWS includes four components: a) detection, monitoring and forecasting potential hazards; b) risk analysis; c) effective dissemination of storm warnings; and d) activation of emergency preparedness and response plans. These need to be coordinated across numerous agencies at both the national and community levels [69].

\section{2) Afforestation}

In order to reduce storm-associated damages, it is necessary to develop sustainable forestry systems along the coastal belts in Bangladesh [70]. Mangroves and non-mangrove coastal forests can play a vital role in reducing storm impacts by acting as a protective shelterbelt during extreme storm events [71]. Mangrove afforestation is a soft adaptation measure that has significantly contributed to reducing fatalities and property damage from tropical cyclones and storm surges in coastal areas [72]. Mangrove forests also serve to conserve and stabilize newly accreted land, contributing to the development of suitable environments for increased biodiversity [73].

\section{3) Homestead and social forestation}

Cyclones are recurrent phenomena in the coastal belt of Bangladesh. To lessen the storm impacts to coastal communities, local Government and several nongovernment institutions (Red Cross) have supplied tree saplings and seedlings for planting in homestead areas. This is an effective strategy for buffering coastal areas from high intensity storms. In coastal belts, forest systems play an important role in reducing wind speeds.

\section{4) Education}

In Bangladesh coastal people are generally not conscious of the timing, frequency and intensity of natural disasters, or associated hazards and existing protection systems [73]. Natural disasters have a profound effect on human health, crops, infrastructure, fish, livestock, households and natural resources. Education concerning these effects should be included in school curriculum to help facilitate awareness in communities regarding natural calamities. Ideally students will learn coping strategies for natural disasters. They in turn will communicate these lessons to their family members and the communities in which they live.

\section{5) Construction of Cyclone shelter}

Cyclone shelters are structures constructed of Reinforced Cement Concrete (RCC) using pillars, with the ground floor being kept open for the free flow of tidal surges [73]. The structural design is prepared in such a way as to withstand with heavy winds and squalls. When storm warnings for cyclones and tidal surges are announced these structures would be opened to provide safe shelter for local communities and livestock. The structures are vacated once the storm warnings are withdrawn. These structures should only be used as temporary cyclone shelters during emergencies and not be treated as shelters for displaced persons.

6) Collaboration with cyclone research system 
Collaborative research between meteorological centers, cyclone disaster management research institutes, and universities needs to focus on updating weather data and warning systems which serve coastal communities. The World Meteorological Organization's (WMO) aim is to make weather data available to tropical cyclone forecasters, and to archive data and other tools which are useful for monitoring and forecasting tropical cyclones [73]. Forecasters may access various sources which provide conventional and specialized datasets/products including numerical predictions and remote sensing observations as well as forecasting tools for tropical cyclone development, motion, intensification and wind distribution. This platform will continue to develop as new datasets and products become available, and will provide a means of sharing forecasting techniques and best practices between cyclone forecast centers.

\subsubsection{Post Disasters Management}

\section{1) Treatment with medicine}

Our recommendations are to re-establish and improve delivery of primary health care. To facilitate this, additional medical supplies and case management training will need to be provided to medical personnel. In order to identify disaster impacts and health needs, public health responders need to be set up to conduct rapid disease risk assessments within the first week of a disaster. Practical, promptly applied control measures, appropriate case management and surveillance systems, are essential for minimizing infectious disease. Natural disasters and infectious disease outbreaks represent global challenges to Millennium Development Goals [72]. It is an important for the general public, policymakers, and health officials to understand the concept that disaster does not transmit infectious diseases; that the primary cause of death in the aftermath of a disaster is non-infectious; that dead bodies (from disasters) are not a source of epidemic; and that infectious disease outbreaks result secondarily from exacerbation of disease risk factors [72]. Education on personal hygiene and proper hand washing procedures, as well as provision of an adequate quantity of safe water, sanitation facilities and appropriate shelter are important for the prevention of infectious diseases during natural disasters. 2) Food supply

Food deficits are a normal situation in disaster prone areas [72]. During disasters, human and livestock foodstuffs, in addition to adequate supplies of potable water, should be immediately available to ensure human wellbeing. Food should be well balanced and free of contaminants. Government and NGO's play a vital role in maintaining an uninterrupted food supply in disaster prone areas.

\section{3) Repairing roads and infrastructure}

Minimizing the impacts of floods and cyclones, and ameliorating future risks from similar storm events, is of vital importance. Priority areas should be identified through community engagement, consultation with local governments, the private sector, NGO's, and other civil organizations [72]. This process needs to include capacity building and training to strengthen the government's disaster preparedness by adopting cost-effective infrastructure design standards and im- 
proving early warning systems. Reconstruction of roads, highways and homes should begin as soon as possible following a natural disaster.

\section{4) Rehabilitation}

Cyclones such as Aila, Sidr and Nargis were devastating to the coastal belt region of Bangladesh. The majority of the infrastructure and dwellings were destroyed during these storms. Residents lost homes, food supplies, and livestock due to the magnitude of these disasters. During this period, the government, along with other organizations, should have recorded the affected families and their houses. Replacement dwellings in disaster prone areas should be designed and constructed appropriately. Displaced people should be resettled in the new homes as quickly as possible.

5) Supply of agriculture seeds, fish and livestock into the affected regions

The economic cost of natural disasters, like cyclones, has been extremely high. Amongst these losses are agriculture crops, fish, and livestock. In this situation, government and non-government institutions need to come up with an umbrella strategy to supply seed, fish and livestock to affected people. Plant seedlings should be distributed and cultivated depending on the disasters longevity.

\section{6) Building awareness}

Natural disaster preparedness plans and coping strategies must include access to accurate forecasts for disaster prone areas. These strategies need to be disseminated to communities through the implementation of seminars and workshops. This will allow local people to learn about mitigation techniques and better adapt to natural disasters. Local communities will in turn inform disaster management strategies through the disaster management bureau and volunteer groups.

\section{Conclusion}

Bangladesh has experienced numerous natural disasters over the last three decades. The effects of tropical cyclones on crops, humans, fish, livestock and households are particularly devastating in the coastal belt. There were many fatalities during tropical storms Sidr and Aila. During these disasters 910.94 and 973.69 ha in crop production were damaged or destroyed. Total losses of cattle (1207), goats (3312), chickens (6853), ducks (1659), buffalo (101) and sheep (142) were noted. Regular monitoring of climatic parameters needs to be connected with natural disasters. We recommend early warning systems, afforestation projects, the construction and repair of more shelter sites, connectivity between natural scientists and policy makers, and dams and levees in coastal areas. Proper management of the coastal belt is important for the economic development of Bangladesh. This research will be significantly helpful for the national development across the coastal belt in Bangladesh as well as throughout the world.

\section{Acknowledgements}

We would like to thank the Agricultural Statistics Division at the Bangladesh Rice Research Institute (BRRI) for providing statistical analysis. We are espe- 
cially thankful to the Bangladesh Ministry of Science and Technology for providing the funding to carry out this research project.

\section{Conflicts of Interest}

The authors declare no conflicts of interest regarding the publication of this paper.

\section{References}

[1] Bennett, R. and Daniel, M. (2002) Media Reporting of Third World Disasters: The Journalist's Perspective. Disaster Prevention and Management, 11, 33-42. https://doi.org/10.1108/09653560210421682

[2] Nahar, N., Blomstedt, Y., Wu, B., Kandarina, I., Trisnantoro, L. and Kinsman, J. (2014) Increasing the Provision of Mental Health Care for Vulnerable, Disaster-Affected People in Bangladesh. BMC Public Health, 14, 708.

https://doi.org/10.1186/1471-2458-14-708

[3] Haque, M.M., Louis, V.R., Phalkey, R. and Sauerborn, R. (2014) Use of Traditional Medicines to Cope with Climate-Sensitive Diseases in a Resource Poor Setting in Bangladesh. BMC Public Health, 14, 202-202. https://doi.org/10.1186/1471-2458-14-202

[4] Disaster Management Bureau (2010) National Plan for Disaster Management. http://www.preventionweb.net/english/professional/policies/v.php?id=16676

[5] Islam, M.R. (2011) Vulnerability and Coping Strategies of Women in Disaster: A Study on Coastal Areas of Bangladesh. The Arts Faculty Journal, 4, 147-168.

[6] Mottaleb, K.A., Mohanty, S., Hoang, H.T.K. and Rejesus, R.M. (2013) The Effects of Natural Disasters on Farm Household Income and Expenditures: A Study on Rice farmers in Bangladesh. Agricultural Systems, 121, 43-52. https://doi.org/10.1016/j.agsy.2013.06.003

[7] Ahamed, S., Rahman, M.M. and Faisal, M.A. (2012) Reducing Cyclone Impacts in the Coastal Areas of Bangladesh: A Case Study of Kalapara Upazila. Journal of Bangladesh Institute of Planners, 5, 185-197.

[8] Bern, C., Sniezek, J., Mathbor, G.M., Siddiqi M.S., Ronsmans, C. and Glass, R.I. (1993) Risk Factors for Mortality in the Bangladesh Cyclone of 1991. Bulletin of the World Health Organization, 71, 73-78.

[9] Wang, H.W., Kuo, P.H. and Shiau, J.T. (2013) Assessment of Climate Change Impacts on Flooding Vulnerability for Low Land Management in Southwestern Taiwan. Nat Hazards, 68, 1001-1019. https://doi.org/10.1007/s11069-013-0670-6

[10] Cyclone Preparedness Program [CPP]. http://www.cpp.gov.bd/

[11] Tarnoff, C. and Lawson, M.L. (2009) Foreign Aid: An Introduction to United States Programs and Policy. DISAM Journal, 31, 102.

[12] Ali, I., Hatta, Z.A. and Azman, A. (2014) Transforming the Local Capacity on Natural Disaster Risk Reduction in Bangladeshi Communities: A Social Work Perspective. Asian Social Work and Policy Review, 8, 34-42. https://doi.org/10.1111/aswp.12023

[13] Spencer, N. and Polachek, S. (2015) Hurricane Watch: Battening Down the Effects of the Storm on Local Crop Production. Discussion Paper, IZA, Bonn, Germany.

[14] Mohan, P. and Strobl, E. (2016) A Hurricane Wind Risk and Loss Assessment of Caribbean Agriculture. Environment and Development Economics, 22, 84-106. https://doi.org/10.1017/S1355770X16000176 
[15] Kassie, M., Shiferaw, B. and Muricho, G. (2011) Agricultural Technology, Crop Income, and Poverty Alleviation in Uganda. World Development, 39, 1784-1795. https://doi.org/10.1016/j.worlddev.2011.04.023

[16] Haque, U., Hashizume, M., Kolivras, K.N., Overgaard, H.J., Das, B. and Yamamoto, T. (2012) Reduced Death Rates from Cyclones in Bangladesh: What More Needs to Be Done? Bulletin of the World Health Organization, 90, 150.

[17] Huang, L.Y., Wang, Y.C., Liu, C.M., Wu, T.N., Chou, C.H., Sung, F.C. and Wu, C.C. (2011) Water Outage Increases the Risk of Gastroenteritis and Eyes and Skin diseases. BMC Public Health, 11, 726. https://doi.org/10.1186/1471-2458-11-726

[18] Matthew, R. (2014) Integrating climate change into peace building. Climatic Change, 123, 1, 83-93. https://doi.org/10.1007/s10584-013-0894-1

[19] Judy, L.B. (2012) Climate Change, Disaster Risk, and the Urban Poor Cities Building Resilience for a Changing World. World Bank Publications, Washington DC, 322.

[20] IPCC (Intergovernmental Panel on Climate Change) (2001) "Summary for Policymakers". Climate Change 2001: Synthesis Report. Contribution of Working Groups I, II and III to the Third Assessment Report of the Intergovernmental Panel on Climate Change. Cambridge University Press, Cambridge, 1-34.

[21] Lin, Y., Zhao, M. and Zhang, M. (2015) Tropical Cyclone Rainfall Area Controlled by Relative Sea Surface Temperature. Nature Communications, 6, Article No. 6591. https://doi.org/10.1038/ncomms7591

[22] Rappaport, E.N. (2000) Loss of life in the United States Associated with Recent Atlantic Tropical Cyclones. American Meteor Society, 81, 2065-2074. https://doi.org/10.1175/1520-0477(2000)081<2065:LOLITU>2.3.CO;2

[23] Weatherford, C.L. and Gray, W.M. (1988) Typhoon Structure as Revealed by Aircraft Reconnaissance. Part I: Data Analysis and Climatology. American Meteor Society, 116, 1032-1043. https://doi.org/10.1175/1520-0493(1988)116<1032:TSARBA>2.0.CO;2

[24] Matyas, C.J. (2010) Association between the Size of Hurricane Rain Fields at Landfall and Their Surrounding Environments. Meteorology and Atmospheric Physics, 106, 135-148. https://doi.org/10.1007/s00703-009-0056-1

[25] Cash, R.A., Halder, S.R., Husain, M., Islam, M.S., Mallick, F.H., May, M. and Rahman, M.A. (2013) Reducing the Health Effect of Natural Hazards in Bangladesh. The Lancet, 382, 2094-2103. https://doi.org/10.1016/S0140-6736(13)61948-0

[26] Paul, S. and Routray, J. (2011) Household Response to Cyclone and Induced Surge in Coastal Bangladesh: Coping Strategies and Explanatory Variables. Natural Hazards, 57, 477-499.

[27] Nath, S.K., Roy, D. and Thingbaijam, K.K.S. (2008) Disaster Mitigation and Management for West Bengal, India-An Appraisal. Current Science, 94, 858-864.

[28] Bangladesh Bureau of Statistics [BBS] (2006) Population Census-2006, Community Series, Zila: Patuakhali. Bangladesh Bureau of Statistic, Ministry of Planning, Government of Bangladesh, Dhaka.

[29] Banglapedia (2011) National Encyclopedia of Bangladesh. Asiatic Society of Bangladesh, Dhaka.

[30] Statistical Pocketbook Bangladesh (2016) Upazila/Thana-Wise Area, Household and Population of Bangladesh, 2001 and 2011. Statistics and Informatics Division (SID), Ministry of Planning, Government of the People's Republic of Bangladesh. 71. 
http://203.112.218.65/WebTestApplication/userfiles/Image/LatestReports/PB2015.p $\underline{\mathrm{df}}$

[31] Alam, M.Z., Carpenter-Boggs, L., Mitra, S., Haque, M.M., Halsey, J., Rokonuzzaman, M., Saha, B. and Moniruzzaman, M. (2017) Effect of Salinity Intrusion on Food Crops, Livestock, and Fish Species at Kalapara Coastal Belt in Bangladesh. Journal of Food Quality, 2017, Article ID: 2045157.

[32] Mahmud, M.H.S., Nahar, N. and Rahman, A. (2014) Challenges for People with Disabilities during Disasters in Bangladesh: An Exploratory Study in Gaibandha District. WFOT Bulletin, 69, 53.

[33] March, G. (2002) Natural Disasters and the Impacts on Health. Faculty of Medicine and Dentistry Summer Student with ICLR-2002, the University of Western Ontario. http://www.eird.org

[34] Gray, C.L. and Mueller, V. (2012) Natural Disasters and Population Mobility in Bangladesh. Proceedings of the National Academy of Sciences of the United States of America, 109, 6000-6005. https://doi.org/10.1073/pnas.1115944109

[35] McDermott, T.K.J. (2012) The Effects of Natural Disasters on Human Capital. http://ssrn.com/abstract $=2011768$

[36] Willem, V.S. (2009) A History of Bangladesh. Cambridge University Press, Cambridge, NY.

[37] Toufique, K.A. and Islam, A. (2014) Assessing Risks from Climate Variability and Change for Disaster-Prone Zones in Bangladesh. International Journal of Disaster Risk Reduction, 10, 236-249. https://doi.org/10.1016/j.ijdrr.2014.08.008

[38] Food and Agriculture Organization (FAO) (2015) The Impact of Natural Hazards and Disasters on Agriculture and Food Security and Nutrition. http://www.fao.org/3/a-i4434e.pdf

[39] Israel, D.C. (2013) Impacts of Natural Disasters on Agriculture, Food Security, and Natural Resources and Environment in the Philippines. Philippine Institute for Development Studies. http://www.eria.org/ERIA-DP-2013-15.pdf

[40] Moni, F.R., Hossen, M.S., Sultana, A., Rumi, M.S., Nahar, B.S. and Baten, M.A. (2013) Impact of SIDR on Crops, Livestock and Fisheries in Some Selected Villages of Pirojpur District of Bangladesh. Journal of Environmental Science and Natural Resources, 6, 25-30.

[41] Röcklinsberg, H. (2015) Fish Consumption: Choices in the Intersection of Public Concern, Fish Welfare, Food Security, Human Health and Climate Change. Journal of Agricultural and Environmental Ethics, 28, 533-551. https://doi.org/10.1007/s10806-014-9506-y

[42] Kumar, U., Baten, M.A., Masud, A.A. Osman, K.S. and Rahman, M.M. (2010) Cyclone Aila: One Year on Natural Disaster to Human Sufferings. http://www.unnayan.org/reports/climate/ailareport_final.pdf

[43] Butler, A.J., Rees, T., Beesley, P., Bax, N.J. and Ropert-Coudert, Y. (2010) Marine Biodiversity in the Australian Region (Australian Marine Diversity). PLoS ONE, 5, e11831.

[44] Sun, M., Chen, B., Ren, J. and Chang, T. (2010) Natural Disaster's Impact Evaluation of Rural Households' Vulnerability: The Case of Wenchuan Earthquake. Agriculture and Agricultural Science Procedia, 1, 52-61. https://doi.org/10.1016/j.aaspro.2010.09.007

[45] Government of Bangladesh (GOB) (2008) Cyclone Sidr in Bangladesh. http://reliefweb.int/sites/reliefweb.int/files/resources/F2FDFF067EF49C8DC12574D 


\section{C00455142-Full_Report.pdf}

[46] Singh, S., Srivastava, P., Abebe, A. and Mitra, S. (2015) Base Flow Response to Climate Variability Induced Droughts in the Apalachicola-Chattahoochee-Flint River Basin, U.S.A. Journal of Hydrology, 528, 550-561.

https://doi.org/10.1016/j.jhydrol.2015.06.068

[47] Jianping, Z., Zhong, Y., Daojie, W. and Xinbao, Z. (2002) Climate Change and Causes in the Yuanmou Dry-Hot Valley of Yunnan, China. Journal of Arid Environments, 51, 153-162. https://doi.org/10.1006/jare.2001.0851

[48] Jones, P.D. and Mann, M.E. (2004) Climate over Past Millennia. Reviews of Geophysics, 42, RG2002/2004.

[49] Loayza, N.V., Olaberría, E., Rigolini, J. and Christiaensen, L. (2012) Natural Disasters and Growth: Going Beyond the Averages. World Development, 40, 1317-1336. https://doi.org/10.1016/j.worlddev.2012.03.002

[50] Intergovernmental Panel on Climate Change [IPCC] (2016). http://www.ipcc.ch/

[51] National Aeronautics and Space Administration (NASA) (2016) Earth Observatory. http://earthobservatory.nasa.gov/Features/RisingCost/rising_cost5.php

[52] Jin, F.F., Boucharel, J. and Lin, I.I. (2014) Eastern Pacific Tropical Cyclones Intensified by El Nino Delivery of Subsurface Ocean Heat. Nature, 516, 82-85.

[53] Emanuel, K. (2005) Increasing Destructiveness of Tropical Cyclones over the Past 30 Years. Nature, 436, 686-688. https://doi.org/10.1038/nature03906

[54] Webster, P.J., Holland, G.J., Curry, J.A. and Chang, H.R. (2005) Changes in Tropical Cyclone Number, Duration, and Intensity in a Warming Environment. Science, 309, 1844-1846. https://doi.org/10.1126/science.1116448

[55] Trenberth, K. (2005) Uncertainty in Hurricanes and Global Warming. Science, 308. 1753-1754.

Van Oldenborgh, G.J., Philip, S. and Collins, M. (2005) El Niño in a Changing Climate: A Multi-Model Study. Ocean Science, 1, 81-95.

[56] Ahmed, N., Occhipinti-Ambrogia, A. and Muir, J.F. (2013) The Impact of Climate Change on Prawn Post Larvae Fishing in Coastal Bangladesh: Socioeconomic and Ecological Perspectives. Marine Policy, 39, 224-233. https://doi.org/10.1016/j.marpol.2012.10.008

[57] Sauerborn, R. and Ebi, K. (2012) Climate Change and Natural Disasters-Integrating Science and Practice to Protect Health. Global Health Action, 5, 1-7.

[58] Pielke, J.R.A., Landsea, C., Emanuel, K., Mayfield, M., Laver, J. and Pasch, R. (2005) Hurricanes and Global Warming. Bulletin of the American Meteorological Society, 86, 1571-1575. https://doi.org/10.1175/BAMS-86-11-1571

[59] Maarten, K.V.A. (2006) The Impacts of Climate Change on the Risk of Natural Disasters. Disasters, 30, 5-18.

[60] Fuglestvedt, J., Shine, K., Berntsen, T., Cook, J., Lee, D., Stenke, A., Skeie, R., Velders, G. and Waitz, I. (2010) Transport Impacts on Atmosphere and Climate: Metrics. Atmospheric Environment, 44, 4648-4677. https://doi.org/10.1016/j.atmosenv.2009.04.044

[61] Ward, P. and Shively, G. (2012) Vulnerability, Income Growth and Climate Change. World Development, 40, 916-927. https://doi.org/10.1016/j.worlddev.2011.11.015

[62] Sura, P. (2011) A General Perspective of Extreme Events in Weather and Climate. Atmospheric Research, 101, 1-21. https://doi.org/10.1016/j.atmosres.2011.01.012 
[63] National Climatic Data Center (2005) Atlantic Hurricane Season. National Climatic Data Center, NOAA, Asheville, NC. http://www.ncdc.noaa.gov/oa/climate/research/2005/hurricanes05.html

[64] Graumann, A., Houston, T., Lawrimore, D.J., Levinson, N., Lott, S., McCown, S., Stephens and Wuertz, D. (2005) Hurricane Katrina-A Climatological Perspective. Preliminary Report. National Climatic Data Centre, National Oceanic \& Atmospheric Administration (NOAA), Asheville, NC.

[65] Vassoler, R.T. and Zebende, G.F. (2012) DCCA Cross-Correlation Co-Efficient Apply in Time Series of Air Temperature and Air Relative Humidity. Physica A: Statistical Mechanics and Its Applications, 391, 2438-2443. https://doi.org/10.1016/j.physa.2011.12.015

[66] Bandyopadhyay, N., Bhuiyan, C. and Saha, A. (2016) Heat Waves, Temperature Extremes and Their Impacts on Monsoon Rainfall and Meteorological Drought in Gujarat, India. Natural Hazards, 82, 367-388. https://doi.org/10.1007/s11069-016-2205-4

[67] Turton, S.M. and Siegenthaler, D.T. (2004) Immediate Impacts of a Severe Tropical Cyclone on the Microclimate of a Rain-Forest Canopy in North-East Australia. Journal of Tropical Ecology, 20, 583-586. https://doi.org/10.1017/S0266467404001622

[68] Corella, J.P., Benito, G., Rodriguez-Lloverasa, X., Brauer, A. and Valero-Garcés, B.L. (2014) Annually-Resolved Lake Record Of Extreme Hydro-Meteorological Events since AD 1347 in NE Iberian Peninsula. Quaternary Science Reviews, 93, 77-90. https://doi.org/10.1016/j.quascirev.2014.03.020

[69] Golnaraghi, M. and Douris, J.-B.M. (2009) Saving Lives through Early Warning Systems and Emergency Preparedness, Risk Wise, Tudor Rose. 137-141.

[70] Michetti, M., Rosa, R. and Michetti, M. (2012) Afforestation and Timber Management Compliance Strategies in Climate Policy. A Computable General Equilibrium Analysis. Ecological Economics, 77, 139-148. https://doi.org/10.1016/j.ecolecon.2012.02.020

[71] Jian, S., Tang, T., Zhong, Y. and Shi, S. (2004) Variation in Inter-Simple Sequence repeat (ISSR) in Mangrove and Non-Mangrove Populations of Heritiera littoralis (Sterculiaceae) from China and Australia. Aquatic Botany, 79, 75-86. https://doi.org/10.1016/j.aquabot.2004.01.005

[72] Nandy, P. and Ahamad, R. (2012) Navigating Mangrove Resilience through the Ecosystem Based Adaptation: Lessons from Bangladesh. Proceedings and A Call for Action from an MFF Regional Colloquium on Mangrove Restoration, Mamallapuram, India, 30-31 August 2012, 243-254.

[73] Papry, R.I. (2014) Status of Coastal Plantation in Chittagong Coastal Forest Division. IOSR Journal of Environmental Sciences, Toxicology and Food Technology, 8 , 79-83. https://doi.org/10.9790/2402-08117983 